\title{
Age-Related Activity Changes in Arginine Phosphokinase in the House Fly, Musca domestica L.'
}

George T. Baker, III, $\mathrm{PhD}^{2}$

\begin{abstract}
The activity of ATP:L-arginine phosphotransferase (E.C.2.7.3.3.), was shown to exhibit agedependent changes in both male and female house fly. Enzyme activity demonstrated more marked changes in the male than in the female, increasing 44-fold from emergence to a peak at 2 days of age and thereafter declining, at first sharply then gradually to a value at 14 days of age, representing a third of the activity found at the peak. Activity in the female fly also showed a peak at 2 days of age, which thereafter declined, although more gradually than was observed in the male. Activity changes expressed on a per fly or wet weight basis were nearly identical. Agerelated activity changes on a milligram protein basis demonstrated similar increases; however, the percentage decrease from the 2-day peaks were less striking, although highly significant. No kinetic or physical changes in the enzyme were detected, nor could any soluble inhibitors or activators of the enzyme be identified. The changes in arginine phosphokinase activity fall into a sequential pattern of enzyme changes, reflecting an apparently ordered mechanism underlying a decline in flight ability in this species.
\end{abstract}

SINCE motor ability is a fundamental biological process, which universally shows a decline in function with advancing age in virtually all species studied, it is appropriate that the biochemical mechanisms involved in motor function be examined in relation to age. The enzyme arginine phosphokinase (APK) is widely distributed among invertebrate species where it functions in a manner analogous to creatine phosphokinase in vertebrate muscle providing the reserve high-energy phosphate necessary for muscle contraction. The essential role of APK in insect muscular activity has been established both directly and indirectly. Kirsten, Kirsten, and Arese (1963) observed changes in arginine phosphate levels in flight and leg muscles of the locust, Locusta migratoria, during muscular activity. In studies on the house fly, Ray and Heslop (1963) reported that following prolonged anoxia (up to 4 hours), during which all motor activity ceases,

\footnotetext{
${ }^{1}$ This work was supported by NICHD Training Grant HD00I42-05 at the Univ. of Miami, School of Medicine. The author wishes to thank Dr. M. Rockstein for his encouragement and support in this work.

2Zoologisch-Vergl. Anatomisches Institut der Universität Zürich, Künstlergasse 16, CH-8806 Zürich.
}

inorganic phosphate concentrations rose, and ATP and arginine concentrations fell markedly; the return of normal motor activity in the fly paralleled the resynthesis of arginine phosphate. Coincident with the initiation of flight, stoichiometric changes in the level of phosphates were demonstrated in vivo in the flight muscle of the blow fly, Phormia regina, by Sacktor and Hurlburt (1966). These authors observed decreases in arginine phosphate and ATP, 10 sec. after the start of flight muscle contraction.

Rockstein and his collaborators have demonstrated a number of age-dependent changes in the adult house fly with advancing age, from a decline in flight ability, changes in activities of various enzymes (alpha-glycerophosphate dehydrogenase, $\mathrm{Mg}$-activated ATPase, and others) and structural components (mitochondria) concerned with the performance of motor function to the structural impairment of flight in the male fly by virtue of wing loss (Rockstein \& Miquel, 1973). Some aspects of this work have been reported earlier by Baker, Rockstein, and Chesky (1970). 


\section{Materials and Methods}

The house flies (Musca domestica L.) employed in these studies were from a highly inbred strain of NAIDM fly colonies reared on a standardized diet as described by Rockstein (1957). Adult flies were maintained on a sugar and water diet and allowed to feed ad libitum. Fly populations were kept under controlled environmental conditions; temperature 26.6 C., $50 \%$ relative humidity, in constant light.

Enzyme extraction.-Flies were sexed, counted, and dissected under $100 \% \quad \mathrm{CO}_{2}$ gas anesthesia. Whole flies or fly tissues (heads or abdomens, legs, and thoraces minus wings and legs) were weighed and immediately frozen in liquid nitrogen. Sample material was extracted in three volumes $(\mathrm{w} / \mathrm{v})$ of ice cold $0.05 \mathrm{M}$ N-ethylmorpholine buffer ( $\mathrm{pH}$ 8.4) for $30 \mathrm{~min}$. at $4 \mathrm{C}$. under constant stirring. The suspension was then centrifuged at 100,000 $\times \mathrm{g}$ for one hour at $4 \mathrm{C}$. Supernatant samples were dialyzed $(1 / 1000 \mathrm{v} / \mathrm{v})$ against $0.05 \mathrm{M}$ $\mathrm{N}$-ethylmorpholine, $\mathrm{pH}$ 8.4, I 0.001 under atmospheric pressure at $0 \mathrm{C}$. for 24 hours.

Enzyme assay.-APK activity was determined by the acid hydrolysis of the phosphoarginine formed and the estimation of the inorganic phosphate released by modification of the methods originally described by Morrison, Griffiths, and Ennor (1957). Final concentrations in the standard reaction mixture were $0.06 \mathrm{M}$ N-ethylmorpholine ( $\mathrm{pH} 8.4), 10 \mathrm{mM}$ L-arginine, $10 \mathrm{mM} \mathrm{ATP}$, and $10 \mathrm{mM} \mathrm{MgSO}_{4}$ in a total volume of $1 \mathrm{ml}$. The reaction mixture was equilibrated in a circulating water bath at $5 \mathrm{C}$. for $2 \mathrm{~min}$. The reaction was started by the addition of appropriate enzyme extracts and stopped after 1 min. by the addition of ice cold $0.2 \mathrm{~N}$ TCA. The reaction tubes were then transferred to a boiling water bath for $1 \mathrm{~min}$., which quantitatively hydrolyses phosphoarginine to arginine and inorganic phosphate. The mixture was then rapidly cooled in an ice bath and filtered through a Whatman No. 42 filter paper. The inorganic phosphate released was then estimated by a modification of the method of Lowry and Lopez (1946). Under these conditions the reaction followed zero order kinetics. Some chemical and kinetic properties of this enzyme from the house fly are described elsewhere by Baker (1971), and a short summary is given at the end of this section. The complete reaction mixture minus L-arginine served as a control. Enzyme activity was expressed as $\mu$ moles of arginine phosphate formed in $1 \mathrm{~min}$. at $5 \mathrm{C}$. per $\mathrm{mg}$ protein, per gram wet weight, or per fly.

Gel preparation.-Gel procedures and preparations were based on original descriptions by Davis (1964), by Ornstein (1964) and by Shapiro, Vinuela, and Maizel (1967). Electrophoresis was carried out in a Tris- $\mathrm{HCl}$ buffer, $\mathrm{pH} 8.6$, at $4 \mathrm{C}$. A current of $2.5 \mathrm{~mA}$ per gel was applied until the dye (Bromphenol blue, $0.005 \%$ ) cleared the stacking gel; thereafter, a constant current of $1.25 \mathrm{~mA}$ per gel was maintained until completion of the runs. Coomassie Brilliant blue was employed as a protein stain. APK activity was assayed on the gel in the following manner: unfixed gels were sliced into $3 \mathrm{~mm}$ slices and placed immediately into ice-cold $10 \mathrm{ml}$ test tubes which contained the complete reaction mixture as described above. Gel slices were incubated overnight in reaction mixture at $4 \mathrm{C}$. The reaction was stopped by the addition of 0.2 $\mathrm{N}$ TCA, and aliquots were removed and assayed for inorganic phosphates as previously described. Duplicate gels were stained for protein and scanned at $600 \mathrm{~nm}$ on a Gilford-2000 Spectrophotometer equipped with a linear scanner. Precise measurements of all gels were taken before and after treatment so that any errors in protein mobilities due to gel shrinkage or swelling could be corrected.

Dry weight determination.-Dry weights of whole flies and fly thoraces were determined according to methods described by Lovegrove (1962). Briefly, flies or fly thoraces were placed in a drying oven at $60 \mathrm{C}$. for $12,18,24,48$, and 72 hours. Samples were removed to a desiccator, allowed to cool, and then weighed. No changes in dry weights were observed after 18 hours of drying, therefore, a drying time of 24 hours was routinely used.

Protein determination.-Protein concentrations were estimated colorimetrically by the method of Gornall, Bardawill and David (1949), or by the method of Lowry, Rosebrough, and Randall (1951), with crystalline serum albumin as the standard.

Enzyme characterization.-The enzyme was found exclusively in the high speed supernatant fraction $(100,000 \times \mathrm{g}, 1$ hour $)$, inhibited by sulfhydryl reagents (complete inhibition by $5 \times 10^{-4} \mathrm{M}$ p-hydroxymercurobenzoate) and 
dependent upon the presence of a divalent metal cation for enzyme activity. $\mathrm{Mg}^{2+}$ ions were shown to be the best activator of the enzyme; however, significant activation was also observed in the presence of $\mathrm{Mn}^{2+}(80 \%)$ and slight activation in the presence of $\mathrm{CA}^{2+}$ ions (5\%). High concentrations of $\mathrm{Mg}^{2+}$ ions markedly inhibited the reaction (apparent $\mathrm{K}_{\mathrm{i}} 14.5$ $\mathrm{mM}$ ). Inhibition was also observed in the presence of $\mathrm{Ni}^{2+}, \mathrm{Hg}^{2+}, \mathrm{Zn}^{2+}, \mathrm{Co}^{2+}, \mathrm{Ca}^{2+}, \mathrm{Fe}^{2+}$, and $\mathrm{Cu}^{2+}$ ions, in decreasing order. The enzyme showed optical specificity with regard to its guanidine substrate L-arginine, and strict specificity with regard to its nucleotidic substrate,

Table 1. Comparative Distribution of ATP:arginine Phosphotransferase in Five-Day old Male and Female House Flies.

\begin{tabular}{|c|c|c|}
\hline \multicolumn{3}{|c|}{$\begin{array}{c}\mu \text { moles Arginine Phosphate Formed/Min } / \mathrm{Mg} \text { Protein at } 5 \mathrm{C} . \\
\text { Male }\end{array}$} \\
\hline Head & 0.060 & 0.029 \\
\hline Thorax & 0.612 & 0.407 \\
\hline Abdomen & 0.032 & 0.102 \\
\hline Legs & 0.517 & 0.035 \\
\hline
\end{tabular}

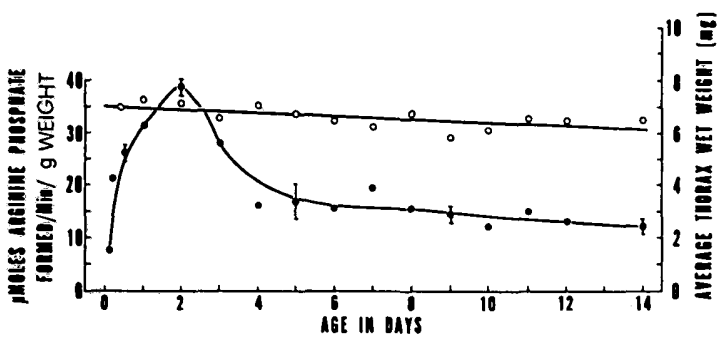

Fig. 1. Arginine phosphokinase activity with age in the male house fly. Activity expressed as $\mu$ moles arginine phosphate formed $/ \mathrm{min} / \mathrm{g}$ wet weight \pm SEM (left axis-solid dots). The average wet weight of the thorax is given in $\mathrm{mg}$ (right axis-open dots). Determinations were compiled from 6-10 generations of flies for the average given at each age.

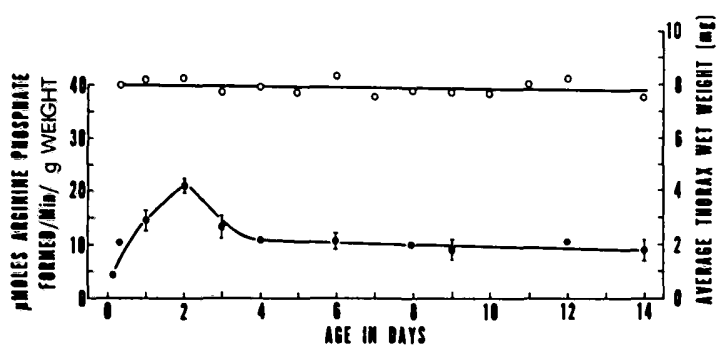

Fig. 2. Arginine phosphokinase activity with age in the female house fly. Activity expressed as $\mu$ moles arginine phosphate formed $/ \mathrm{min} / \mathrm{g}$ wet weight $\pm \mathrm{SEM}$ (left axis-solid dots). The average wet weight of the thorax is given in $\mathrm{mg}$ (right axis-open dots). Determinations were compiled from 6-10 generations of flies for the average given at each age.
ATP. The $\mathrm{pH}$ optimum for the forward reaction was determined to be 8.4 , and the apparent $\mathrm{Km}$ for $\mathrm{L}$-arginine to be $0.84 \pm 0.15$ $\mathrm{mM}$. Classical substrate inhibition was observed in the presence of high concentrations of L-arginine (apparent $\mathrm{K}_{\mathrm{i}} 22.5 \mathrm{mM}$ ). The enzyme migrated as a single homogeneous band on urea-SDS polyacrylamide gels and was estimated to have a molecular weight of $40,800 \pm 1,400$ daltons, from determination of the frictional ratio. Results of initial velocity studies of the forward reaction at low substrate concentrations suggest that the reaction mechanism is of a sequential type. These data are similar to those found for APK in other insects (Cheung, 1973; Wallimann \& Eppenberger, 1973).

\section{Results}

Preliminary investigations demonstrated that the enzyme activity was located only in the $100,000 \times \mathrm{g}$ supernatant fraction. It was further demonstrated that the largest amount of enzyme was found in the thorax. Table 1 illustrates the distribution of enzyme activity in 5-day-old male and female house flies. The legs, particularly those of the male flies, were shown to have high levels of enzyme activity. Since the thoraces of both the male and the female house flies demonstrated the highest levels of enzyme activity, more detailed studies were carried out on carefully dissected thoraces of aging male and female house flies. Fig. 1 shows the changes in enzyme activity in thoraces of male house flies with advancing age on a gram wet weight basis. As many as 10 generations (6-10) of male flies are represented at each point in these experiments. The standard error of the means is given at selected points and is not given at all points for the sake of clarity. Enzyme activity was observed to increase some 44-fold from emergence until a peak at 2 days. A similar rise in activity (44-fold) was observed on a per fly basis. The decline in enzyme activity was similar on a per fly and a wet weight basis having decreased at 14 days of age to $33 \%$ of the peak. Also shown in Fig. 1, is the best fit line by least square analysis for the weight in $\mathrm{mg}$ of a single male thorax with advancing age (righthand axis). The male thorax gradually lost $1 \mathrm{mg}$ of its initial weight from emergence to 14 days of age ( $p>0.05$ Student-T test). Fig. 2 demonstrates the changes of APK activity 
in the thoraces of adult female house flies. Enzyme activity was observed to increase some 32 -fold from emergence to a peak at 2 days. This increase is somewhat less than the increase observed in the male which occurred at the same time. By 14 days of age, enzyme activity declined to a level of $48 \%$ of that observed at 2 days. There was no statistically signifioant difference in the weight of the female thorax from emergence through 14 days of age. Activity changes expressed on a per female thorax basis were similar to those observed on a wet weight basis.

When enzyme activity was expressed on a mg protein basis (see Fig. 3 ) in the male house fly, the observed decline in enzyme activity was statistically significant $(p>0.001)$; however, it was not as great as that observed on a gram wet weight or per fly basis. The initial rise in activity, however, was identioal. The best fit line by least square analysis demonstrates no differences in the total amount of soluble pro-

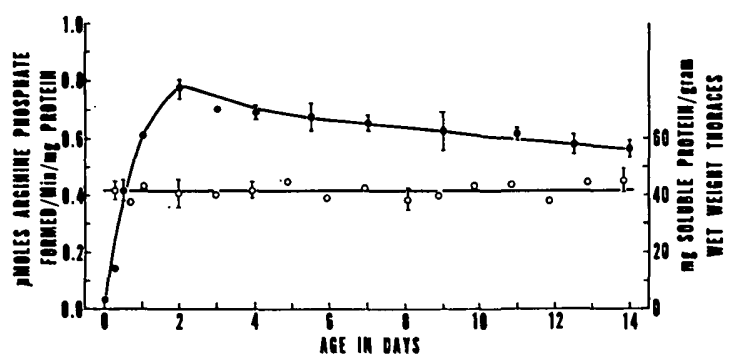

Fig. 3. Arginine phosphokinase activity with age in the male house fly. Activity expressed as $\mu$ moles arginine phosphate formed $/ \mathrm{min} / \mathrm{mg}$ protein $\pm \mathrm{SEM}$ (left axis-solid dots). 'The $\mathrm{mg}$ of soluble protein $(100,000 \times \mathrm{g}$ supernatant fraction) per $\mathrm{g}$ wet weight of thoraces is presented on the right axis (open dots \pm $\mathrm{SEM})$. Six to ten generations of flies are represented at each age.

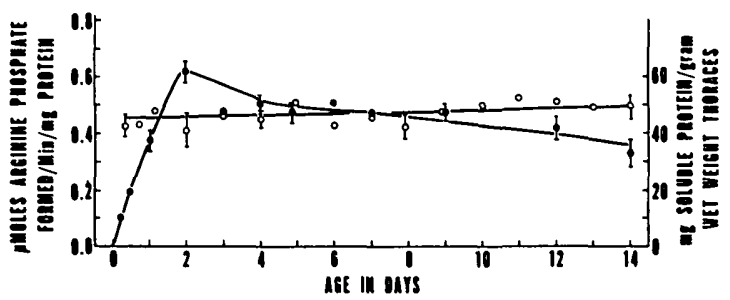

Fig. 4. Arginine phosphokinase activity with age in the female house fly. Activity expressed as $\mu$ moles arginine phosphate formed $/ \mathrm{min} / \mathrm{mg}$ protein \pm SEM (left axis-solid dots). The $\mathrm{mg}$ of soluble protein $(100,000 \times \mathrm{g}$ supernatant fraction) per $\mathrm{g}$ wet weight of thoraces is presented on the right axis (open dots \pm $\mathrm{SEM})$. Six to ten generations of flies are represented at each age. tein from emergence through 14 days of age. Fig. 4 gives the same activity changes per milligram protein and milligram of soluble protein per gram wet weight for adult female flies with advancing age. As was observed in the male thorax, the increase in activity was similar to that observed on a wet weight basis, however, the decline, although statistically significant $(p>0.001)$, was not as great as that observed on a gram wet weight basis. No significant changes in the amount of soluble protein per gram wet weight were observed from emergence through 14 days of age in the female thorax.

The average wet weight of thoraces and whole male and female house flies from a single generation and the percentage of that weight as water is shown in Table 2. Each value represents the average of 6 samples (20 individuals) and the standard error of the mean, treated as described in the Methods. A continued loss in weight was observed from emergence to old age for the thoraces as well

Table 2. Average Weights and Percentage of Body Weight as Water of Male and Female Flies and

\begin{tabular}{|c|c|c|c|c|}
\hline \multirow[b]{2}{*}{ Age } & \multicolumn{2}{|c|}{ Thorax } & \multicolumn{2}{|c|}{ Whole Animal } \\
\hline & $\begin{array}{c}\text { Average } \\
\text { Wet Weight } \\
\text { (mg) }\end{array}$ & $\begin{array}{c}\% \text { of } \\
\text { Thorax Weight } \\
\text { as Water }\end{array}$ & $\begin{array}{c}\text { Average } \\
\text { Wet Weight } \\
\text { (mg) }\end{array}$ & $\begin{array}{c}\% \text { of } \\
\text { Body Weight } \\
\text { as Water }\end{array}$ \\
\hline \multicolumn{5}{|c|}{ Male } \\
\hline 1 hour & $5.78 \pm 0.05$ & $21.5 \pm 0.63$ & $12.89 \pm 0.51$ & $23.7 \pm 0.25$ \\
\hline 1 day & $5.55 \pm 0.07$ & $28.5 \pm 0.50$ & $11.04 \pm 0.40$ & $32.6 \pm 0.38$ \\
\hline 2 day & $5.34 \pm 0.43$ & $34.6 \pm 1.02$ & $9.53 \pm 0.68$ & $34.0 \pm 2.75$ \\
\hline 5 day & $5.30 \pm 0.03$ & $28.6 \pm 0.14$ & $9.29 \pm 0.48$ & $31.8 \pm 0.53$ \\
\hline 12 day & $5.15 \pm 0.06$ & $29.2 \pm 1.01$ & $10.94 \pm 0.31$ & $22.8 \pm 0.61$ \\
\hline \multicolumn{5}{|c|}{ Female } \\
\hline 1 hour & $6.27 \pm 0.07$ & $19.1 \pm 0.27$ & $15.23 \pm 1.01$ & $22.9 \pm 0.60$ \\
\hline 1 day & $6.18 \pm 0.04$ & $28.6 \pm 1.04$ & $15.37 \pm 0.04$ & $34.2 \pm 0.87$ \\
\hline 2 day & $6.06 \pm 0.03$ & $31.8 \pm 0.62$ & $13.58 \pm 0.03$ & $34.6 \pm 0.13$ \\
\hline 5 day & $6.04 \pm 0.61$ & $29.0 \pm 0.20$ & $13.84 \pm 0.17$ & $35.4 \pm 1.04$ \\
\hline 12 day & $5.39 \pm 0.20$ & $33.0 \pm 0.66$ & $13.73 \pm 0.87$ & $31.7 \pm 0.41$ \\
\hline
\end{tabular}

Table 3. Mobilities of ATP:arginine Phosphotransferase of Male Fly Preparations at Different Ages on 10\% Polyacrylamide Gels.

\begin{tabular}{|c|c|c|}
\hline \multicolumn{3}{|c|}{ Thoraces } \\
\hline Age & Protein $\mathrm{Mg}$ & Mobility \\
\hline 10 hour & 38.2 & 465 \\
\hline 10 hour & 19.1 & 465 \\
\hline 7 day & 17.72 & 472 \\
\hline 7 day & 17.72 & 473 \\
\hline 14 day & 29.08 & 471 \\
\hline 14 day & 18.54 & 473 \\
\hline \multicolumn{3}{|c|}{ Legs } \\
\hline 10 hour & 22.5 & 474 \\
\hline 14 day & 17.45 & 465 \\
\hline
\end{tabular}


as the whole animal in both the male and female fly. However, the percentage of that weight as water increased from emergence until 2 days and thereafter declined in both the thoraces and the whole animals.

Table 3 presents a summary of the relative mobilities of APK from thoraces and legs of various aged male flies at different protein concentrations. Essentially, no differences in the mobilities of APK from the thorax or the leg preparations at different ages could be detected, nor was there any indication of isozymes. Consistent with arginine phosphokinase being a major soluble muscle protein, Table 4 shows that this enzyme constitutes a significant fraction of the $100,000 \times \mathrm{g}$ proteins in both the thorax and leg extracts. Estimates were obtained by integrating the total area under densitometer scans and the percentage of that identified as APK was calculated.

The distribution of APK activity from a single generation of male house flies is presented in Table 5. The thorax and leg preparations demonstrated the most striking changes in enzyme activity, whereas, the head and abdo-

Table 4. Relative Amount of Total Cytoplasmic Protein as ATP:arginine Phosphotransferase in Aging Male House Fly Thoraces and Legs.

\begin{tabular}{lcc}
\hline & \multicolumn{2}{c}{ \% Enzyme Protein } \\
Age & Thorax & Legs \\
\hline 10 hour & 14.4 & 15.9 \\
7 day & 16.2 & - \\
14 day & 14.5 & 20.3 \\
\hline
\end{tabular}

Table 5. Distribution of ATP:arginine

Phosphotransferase Actvity in a

Single Generation of Aging Male House Flies.

\begin{tabular}{ccccc}
\hline \hline Age & Head & Thorax & Abdomen & Legs \\
\hline 4 hours & 0.016 & 0.420 & 0.005 & 0.345 \\
10 hours & 0.020 & 0.417 & 0.030 & 0.305 \\
2 days & 0.020 & 0.864 & 0.055 & 1.140 \\
5 days & 0.060 & 0.420 & 0.042 & 0.517 \\
14 days & 0.085 & 0.573 & 0.008 & 0.219 \\
\hline (Activity $\mu$ moles arginine phosphate formed $/ \mathrm{mg} / \mathrm{min}$ at $5 \mathrm{C}$.
\end{tabular}

men sections of the flies demonstrated little activity and smaller changes. These data are consistent with APK being primarily a muscle enzyme. Presented in Table 6 are the Michaelis constants and maximum velocities for APK in aging male thoraces at various ages. Each value represents at least 6 determinations along with the standard error of the mean. No significant differences in the apparent $\mathrm{Km}$ for L-arginine or for other substrates were observed. The maximum velocities are expressed on a per $\mathrm{mg}$ protein basis which was shown not to change with advancing age. Moreover, it is unlikely that the observed changes in activity are due to activators being present in the young or old animals, respectively, since the addition of old homogenates back to young preparations and vice versa yielded activity which would be expected on the basis of the individual activities only. In that aging per se encompasses all stages of life, enzyme activity was examined during the developmental stages of the fly (Fig. 5). Activity is expressed in $\mu$ moles of arginine phosphate formed $/ \mathrm{min} / \mathrm{mg}$ protein.

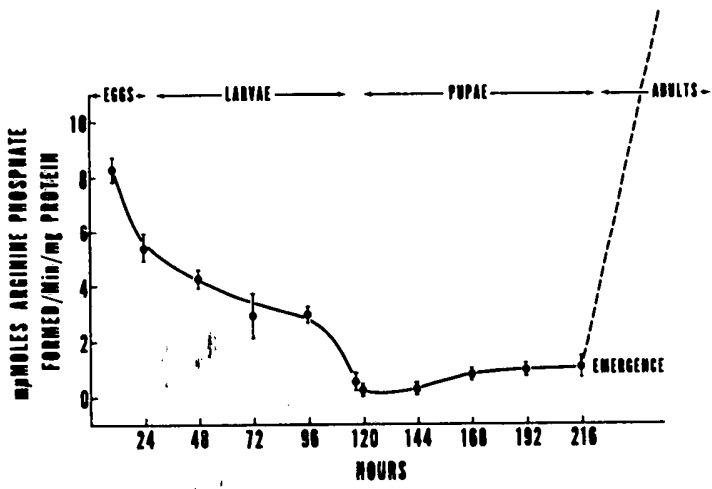

Fig. 5. Arginine phosphokinase activity during developmental stages of the house fly. Activity expressed as $\mu$ moles arginine phosphate formed $/ \mathrm{min} / \mathrm{mg}$ protein. Each age represents the average of 6 determinations \pm SEM.

Table 6. Michaelis Constants and Maximum Velocities of ATP:arginine Phosphotransferase from Aging Male Thoraces.

\begin{tabular}{|c|c|c|c|c|c|c|}
\hline \multirow[b]{2}{*}{ Age } & \multirow{2}{*}{\multicolumn{2}{|c|}{$\begin{array}{l}\text { Kms } \\
(\mathrm{mM}) \\
\text { ATP }\end{array}$}} & \multirow[b]{2}{*}{$\mathrm{Mg}^{2}+$} & \multicolumn{3}{|c|}{$\begin{array}{c}V \max \\
(\mu \text { moles arginine phosphate formed } / \mathrm{min} / \mathrm{mg})^{\mathbf{n}}\end{array}$} \\
\hline & & & & Arginine & ATP & $\mathrm{Mg}^{2}+$ \\
\hline 4 hours & $1.15 \pm 0.22$ & $1.89 \pm 0.72$ & $1.23 \pm 0.95$ & $0.526 \pm 0.031$ & $0.704 \pm 0.076$ & $0.526 \pm 0.101$ \\
\hline 2 day & $0.84 \pm 0.15$ & $2.86 \pm 1.00$ & $2.86 \pm 0.81$ & $0.951 \pm 0.049$ & $1.163 \pm 0.121$ & $1.165 \pm 0.135$ \\
\hline 6 day & $1.44 \pm 0.75$ & $2.50 \pm 0.85$ & $2.50 \pm 0.56$ & $0.571 \pm 0.085$ & $0.503 \pm 0.031$ & $0.530 \pm 0.042$ \\
\hline 9 day & $1.59 \pm 0.50$ & $2.77 \pm 0.63$ & $2.38 \pm 0.72$ & $0.476 \pm 0.052$ & $0.520 \pm 0.062$ & $0.588 \pm 0.048$ \\
\hline 14 day & $1.84 \pm 0.53$ & $2.48 \pm 0.65$ & $2.42 \pm 0.93$ & $0.520 \pm 0.034$ & $0.556 \pm 0.057$ & $0.575 \pm 0.045$ \\
\hline
\end{tabular}

- Enzyme activity expressed per milligram of total thorax supernatant $(100,000 \mathrm{x} \mathrm{g})$ protein, which showed no statistically significant changes with age. 
Freshly laid, buffer washed eggs were observed to contain significantly greater amounts of enzyme activity than was observed in later stages of metamorphosis.

\section{Discussion}

The comparative distribution of APK in the house fly in various body sections (Table 5) is in accordance with this enzyme being primarily a muscle enzyme. The relatively high activity found in freshly laid eggs in comparison with other developmental stages is unexpected. Low levels of APK activity were reported in eggs from Drosophila melanogaster by Wallimann and Eppenberger (1973).

The male thorax was observed to have higher APK activities as compared to any similar aged female thorax, particularly on a wet weight basis which may, in part, be explained by the greater amount of protein contained in and the greater wet weight of the female thorax. Other factors, such as the absence of protein in the diet of the female flies, which is essential for maximal longevity, could possibly play a role (Gray \& Berberian, 1971).

No differences were observed in the pattern of activity changes whether enzyme activity was expressed per milligram protein, per fly, or per gram wet weight, however, the magnitude of the observed changes, particularly of the decrease in both male and female fly thoraces, was less when expressed on a milligram protein basis. Such inconsistencies serve to illustrate that in any attempt to analyze the significance or functionality of age-related changes, care must be exercised in the manner of expression.

Since no soluble activators or inhibitors of APK activity were observed, it is concluded that the observed changes in activity were the result of altered synthesis and/or degradation, or in the amount of active enzyme present. The former is especially plausible with regards to the initial rise in activity, as the changes in activity were similar regardless of the manner of expression and in view of the fact that no significant differences in the amount of soluble protein were observed.

The changes in the activity of APK fall into a now well-established sequence of enzyme changes related to the maturation and senescence of flight function in this strain of house fly. The male fly exhibits a 50\% mortality of 11.5 days and female of 15.8 days (Gray \& Berberian, 1971). In the male fly, where flight ability in terms of duration of flight reaches a peak approximately 1 day post-emergent and the onset of wing loss occurs at 4-5 days of age, a remarkable (integrated) pattern in the failure of enzyme systems concerned with the energizing of flight muscle unfolds. The activity of natural actomyosin shows a peak at approximately I day of age coincident with maximal flight ability (Rockstein \& Chesky, 1973). Two days following emergence, APK reaches a peak and thereafter declines, thus limiting the amount of readily available ATP for flight. Approximately 36 hours later, the activity of alpha-glycerophosphate dehydrogenase begins to decline further limiting oxidative energy production by reducing the amounts of available substrates (Rockstein \& Brandt, 1963). Coincident with the onset of wing loss (4-5 days), the activity of thoracic intramitochondrial Mg-activated ATPase declines. The failure of these enzyme systems prior to and concomitant with the actual loss of flight ability suggest a programmed chemical senescence which is genetically manifested in an orderly fashion.

\section{SumMary}

The activity of arginine phosphokinase, an enzyme important in the energy metabolism of insect flight muscle, demonstrates agedependent changes which are associated with a decline in flight ability in the aging house fly. No inhibitors or activators of the enzyme were identified nor were any kinetic or physical properties of the enzyme shown to differ with age. Activity changes are therefore assumed to be due to alterations in the rate of synthesis and/or degradation or to the synthesis of impaired enzyme. The activity changes reported for arginine phosphokinase fall into a now well-established sequential pattern of biochemical senescence underlying the physiological decline of flight ability with age in this Dipteran species.

\section{REFERENCES}

Baker, G. T. III. Properties of ATP:L-arginine phosphotransferase in the aging house fly, Musca domestica L. PhD Dissertation, Univ. of Miami (Fl.), 1971. 
Baker, G. T., Rockstein, M., \& Chesky, J. Age-dependent changes in arginine kinase activity in Musca domestica L. Gerontologist, 1970, 10, (3:2) 27. (abstract)

Cheung, A. C. Kinetic properties of arginine phosphokinase from honeybees, Apis mellifera L. (Hymenoptera, Apidae). Archives Biochemistry \& Biophysics, 1973, 154, 28-39.

Davis, B. J. Disc electrophoresis-II. Method and application to human serum proteins. Annals New York Academy of Science, 1964, 121, 404-427.

Gray, F. H., \& Berberian, P. A. The effect of limited milk feeding on the longevity of the house fly, Musca domestica. L. Experimental Gerontology, 1971, 6, 205-210.

Gornall, A. G., Bardawill, C. J., \& David, M. M. Determination of serum proteins by means of the biuret reaction. Journal of Biological Chemistry, 1949, 177, 751-766.

Kirsten, E., Kirsten, R., \& Arese, P. Das verhalten von freien Aminosauren, energiereichen Phosphorsaureverbindungen und einigen glykolyreund tricarbonsauren las-substraten in Muskeln von Locusta migratoria bei der Arbeit. Biochemische Zeitschrift, 1963, 337, 167-178.

Lovegrove, $\mathrm{T}$. The effect of various factors on dry weight values. Rapports et Proces-Verbaux des Reunions, 1962, 153, 86-91.

Lowry, O. H., \& Lopez, J. A. Determination of inorganic phosphate in the presence of labile phosphate esters. Journal of Biological Chemistry, 1946, 162, 421-428.

Lowry, O. H., Rosebrough, N. J., \& Randall, R. J. Protein measurement with the Folin phenol reagent. Journal of Biological Chemistry, 1951, 193, 265-275.

Morrison, J. F., Griffiths, D. E., \& Ennor, A. M. Purifi- cation and properties of arginine phosphokinase. Biochemical Journal, 1957, 65, 143-153.

Ornstein, L. Disc electrophoresis-I. Background and theory. Annals New York Academy of Science, 1964, 121, 321-349.

Ray, J. W., \& Heslop, J. P. Phosphorous metabolism of the house fly (Musca domestica L.) during recovery from anoxia. Biochemical Journal, 1963, 87, $39-42$.

Rockstein, M. Longevity of male and female house flies. Journal of Gerontology, 1957, 12, 235-256.

Rockstein, M., \& Brandt, K. F. Enzyme changes in flight muscle correlated with aging and flight ability in the male house fly. Science, 1963, 139, 1049-1051.

Rockstein, M., \& Chesky, J. Age-related changes in natural actomyosin of the male house fly, Musca domestica L. Journal of Gerontology, 1973, 28, 455459.

Rockstein, M., \& Miquel, J. Aging in insects. In M. Rockstein (Ed.), The physiology of insecta, Vol. 1. Academic Press, New York, 1973.

Sacktor, B., \& Hurlburt, E. C. Regulation of metabolism in working muscle in vivo-II concentration of adenine nucleotides, arginine phosphate, and inorganic phosphate in insect flight muscle during flight. Journal of Biological Chemistry, 1966, 241, 632-634.

Shapiro, A. L., Vinuela, E., \& Maizel, J. V. Molecular weight estimation of polypetide chains by electrophoresis in SDS-polyacrylamide gels. Biological $\mathcal{E}$ Biophysical Research Communications, 1967, 28, 815920.

Wallimann, T., \& Eppenberger, H. M. Properties of arginine kinase from Drosophila melanogaster. European Journal of Biochemistry, 1973, 38, 180-184. 